\title{
EXAMINING THE RELATIONSHIPS AMONG ANTECEDENTS OF BEHAVIOURAL INTENTIONS IN ADVENTURE SPORTS CONTEXT
}

\author{
JYOTI KUMAR CHANDEL', SAT PRAKASH BANSAL2, SAID GATTOUFI ${ }^{3}$ \\ ${ }^{1}$ Waljat College of Applied Sciences, Department of Management, Rusayl, Oman \\ 2Indira Gandhi University, Meerpur, India \\ ${ }^{3}$ University of Tunis, Institut Supérieur de Gestion de Tunis, Department of Economics and \\ Quantitative Methods, Tunis, Republic of Tunisia
}

\begin{abstract}
Mailing address: Jyoti Kumar Chandel, Waljat College of Applied Sciences, Department of Management, P.O. Box 197, P.C. 124, Al Rusayl, Muscat, Sultanate of Oman, tel.: +968 24446660 ext. 237, fax: +968 24449197, e-mail: jkchandel@gmail.com
\end{abstract}

\begin{abstract}
Introduction. This study aims to examine the structural relationships between value, satisfaction, and behavioural intentions among adventure sports trainees through Partial Least Square Structural Equation Modelling (PLS-SEM). The constructs of service value and satisfaction have been examined as antecedents of behavioural intentions. Material and methods. The conceptual model was tested with primary data which were collected - through multistage sampling - from 230 participants of adventure sports training in Himachal Pradesh, India using Partial Least Square Structural Equation Modelling (PLS-SEM). Results. Functional value, emotional value, and novelty value were found to significantly influence satisfaction, as hypothesised, while social value and value for money had an insignificant influence on the satisfaction of adventure trainees. Satisfaction was shown to have a significant influence on the intention to revisit, the search for alternatives, and word-of-mouth referral as behavioural intentions of adventure trainees. Conclusions. This study has confirmed the significant positive influence of functional value, emotional value, and novelty value on adventure trainees' satisfaction. Satisfaction has a direct positive influence on the intention to revisit and word-of-mouth referrals, while it has a negative influence on the search for alternatives. Satisfaction has been found to have a partial mediation effect on the relationships between the five dimensions of service value and behavioural intentions.
\end{abstract}

Key words: adventure training, behavioural intentions, emotional value, functional value, novelty value, satisfaction, social value, value for money

\section{Introduction}

Adventure training is considered one of the important facilitators to adventure tourism, adventure sports, and outdoor and experiential learning. It also provides a strong foundation required for the growth of these areas by capacity building through education and training programmes. Adventure training programmes are designed to achieve anticipated outcomes in trainees by imparting the knowledge, skills, and attitudes required. These programmes are broadly classified on the basis of anticipated outcomes as recreational, educational, developmental, and therapeutic [1]. Adventure education and training programmes have witnessed growth in the past, and the number of adventure training centres has increased in different parts of the world to meet the growing demand for adventure education and training. At the same time, adventure training centres have also witnessed an increase in competition to earn more profit and gain significant market shares. The increase in competition has forced many of these centres to gain a better understanding of the pre- and post-consumption behaviour of adventure trainees for better alignment of their offerings with the expectations of adventure trainees.

The existing literature in the fields of adventure tourism, adventure sports, and adventure education and training offers a limited number of studies from the perspective of service marketing and management. The current study is an attempt to fill the existing knowledge gap by exploring the aspect of service evaluation in adventure education and training. The constructs of perceived service value, satisfaction, and future behavioural intentions have been explored in the area of adventure sports training. The main objective of this study is to examine relationships between perceived service value, satisfaction, and future behavioural intentions in adventure sports trainees and to test a conceptual model for the evaluation of services in adventure education and training. Understanding these relationships can help the management of adventure education and training organisations to design and deliver adventure training programmes in such a way that the satisfaction of adventure trainees can be enhanced to elicit positive future behaviour. The model tested will also facilitate the prediction of adventure training participants' satisfaction and future behavioural intentions based upon their perception of service value.

This study was conducted on adventure sports trainees in different adventure sports training centres in Himachal Pradesh offering various training programmes in trekking, rock climbing, mountaineering, adventure, water sports, skiing, and mountain biking. 


\section{Literature review}

\section{Service value}

Service value has been defined as the proportion of benefits to cost [2]. A multidimensional perspective of service value is considered more appropriate in predicting customers' behavioural intentions in the context of services than a utilitarian, functional view of value [3]. Sweeney and Soutar [4] have developed the PERVAL framework for examining service value. It consists of the five dimensions of service value viz. functional value, value for money, social value, emotional value, and epistemic value. The PERVAL framework was adapted by Sweeney and Soutar from Sheth et al. [5].

Sheth et al. [5] have defined functional value as the "perceived utility acquired from an alternative's capacity for functional, utilitarian or physical performance". Value for money is expressed as the price paid for the product or service by the customer [3]. Emotional value is stated as the product's capacity to stimulate emotions [5]. Sheth et al. [5] have stated that social value is "the perceived utility acquired from an alternative's association with one or more specific social groups". Epistemic value (novelty value) is regarded as a key component of value among adventure participants, and it concentrates on the novelty of the event [6]. Novelty and the search for new knowledge are important factors which influence tourists [7].

\section{Customer satisfaction}

Customer satisfaction is considered to be one of the core goals of marketing activities. Most business organisations practice regular monitoring of customer satisfaction [8]. Customer satisfaction is an important construct for organisations, and it is also an indicator of organisational performance [9]. In the context of tourism, tourist satisfaction is examined as an experiential rather than attribute-based construct because it represents an affective state of mind after the experience [10].

\section{Consumer behavioural intentions}

According to Zeithaml, Berry, and Parasuraman [11], favourable behavioural intentions of customers are associated with the level of their satisfaction with the services, and they may be expressed in the form of saying positive words, loyalty by future patronage, recommendation to other customers, and an increase in spending. This study has adopted the intention to revisit, the search for alternatives, and word-of-mouth referral as constructs for measuring the behavioural intentions of adventure trainees.

\section{Relationship between perceived service value and customer satisfaction}

Many researchers have examined the relationship between perceived service value and customer satisfaction for different services, and several studies have reported the influence of perceived service value on customer satisfaction $[12,13,14,15,16$, 17]. Bojanic [18] has reported a strong correlation between the service value and satisfaction constructs in the tourism context.

A multidimensional view of service value is reported to be more suitable in the context of services [3]. As already mentioned, Sweeney and Soutar [4] have developed the PERVAL framework which offers a multidimensional perspective on service value, with functional value, social value, emotional value, value for money, and epistemic value (novelty value) as its five dimensions. Relationships between these five dimensions of service value and customer satisfaction have been studied in different contexts.
Functional value is regarded as an important dimension of service value in the adventure context due to inherent risk- and safety-related issues in adventure-related activities [19]. Functional value is deemed to positively influence customer satisfaction [20, 21, 22, 23]. Hence, we have put forward five hypotheses.

$\mathrm{H}_{1}$. Functional value has a direct influence on the satisfaction of adventure trainees.

Researchers have explored the relationship between the constructs of value for money and satisfaction in different service contexts. Value for money has been reported to positively influence customer satisfaction $[23,24]$. Therefore, the following hypothesis has been proposed in the context of adventure training:

$\mathrm{H}_{2}$. Value for money has a direct influence on the satisfaction of adventure trainees.

Participation in adventure activities is also influenced by the emotions of the participants, and variance in satisfaction is reported to be explained through the emotional responses of customers in the adventure sector [25]. Emotional value is defined as the product's capability to trigger feelings [5]. Since it is considered to influence customer satisfaction [23], we hypothesise as follows:

$\mathrm{H}_{3}$. Emotional value has a direct influence on the satisfaction of adventure trainees.

Social value is stated to satisfy the social and psychological needs of consumers. These needs can be satisfied in small groups. Social value is considered to positively influence customer satisfaction $[20,21,23]$. Hence, we hypothesise the following:

$\mathrm{H}_{4}$. Social value has a direct influence on the satisfaction of adventure trainees.

Feng and Jang [26] have reported novelty-seeking tendencies among tourists in terms of the destinations visited. Novelty value tends to positively influence customer satisfaction in the adventure tourism context $[20,23]$. Therefore, we have formulated the following hypothesis:

$\mathrm{H}_{5}$. Novelty value has a direct influence on the satisfaction of adventure trainees.

\section{Relationship between satisfaction and behavioural intentions of customers}

Several studies conducted in different services suggest that customer satisfaction directly affects loyalty and future behavioural intentions [17, 27, 28, 29, 30, 31, 32, 33].

Prior research studies in the area of tourism have suggested that customer satisfaction has a positive significant impact on the intention to revisit $[16,20,34,35]$. Therefore, we have formulated the following hypothesis:

$\mathrm{H}_{6}$. The satisfaction of adventure trainees has a direct influence on their intention to revisit.

The search for alternatives has been suggested to be a consequence of customer dissatisfaction among tourists [16, 20, 36]; thus, a negative relationship exists between customer satisfaction and the search for alternatives. Therefore, we have hypothesised as follows:

$\mathrm{H}_{7}$. The satisfaction of adventure trainees influences their search for alternatives.

Word-of-mouth referrals play a very important role in influencing the purchase-related decisions of other customers, and word-of-mouth referrals are positively influenced by customer satisfaction $[16,20,34]$. Hence, the following hypothesis is proposed:

$\mathrm{H}_{8}$. The satisfaction of adventure trainees influences their word-of-mouth referrals. 


\section{Mediating role of customer satisfaction in the relationship between service value and behavioural intentions}

It has been suggested that service value affects customer satisfaction, and, subsequently, customer satisfaction affects behavioural intentions. Customer satisfaction thus mediates between service value and the behavioural intentions of customers $[23,37,38]$. Therefore, we hypothesise the following:

$\mathrm{H}_{9}$. The satisfaction of adventure trainees mediates totally or partially in the relationship between service value and behavioural intentions.

\section{Conceptual model}

The proposed conceptual model has been developed on the basis of the literature review. It has been devised for testing different relationships between the constructs of service value, satisfaction, and behavioural intentions in participants in adventure education and training.

\section{Material and methods}

\section{Sampling procedure and data collection}

Participants of adventure sports training programmes in the state of Himachal Pradesh (India) were surveyed, and multistage sampling was carried out for the purposes of the study. Districts with high number of training centres offering adventure training were selected in the first stage of sampling. This resulted in the selection of the Shimla, Bilaspur, Kangra, Kullu, Chamba, Lahaul, and Spiti districts for the survey. During the second stage of sampling, training centres which organised adventure training programmes regularly were chosen from these districts to get maximum response. In the next step, chronological lists of similar adventure training programmes offered by these adventure training centres were prepared on a quarterly basis, and these training programmes were treated as clusters. Adventure training programmes were chosen on the basis of systematic random sampling for data collection from the participants. Alternate adventure training programmes were chosen for primary data collection. Participants who expressed the willingness to participate in the survey were administered the questionnaire. Data were collected continuously for twelve months to include adventure training participants of seasonal adventure training programmes as well. Questionnaires were administered to 500 adventure training participants, and 230 questionnaires were returned; thus, the response rate was $46 \%$. The questionnaire had 32 items linked with the constructs of service value, satisfaction, and behavioural intentions and 9 items related to demographics.

\section{Measures}

The scales for the measurement of emotional value, functional value, social value, and value for money were adapted from Sweeney and Soutar [4], while the scale for the construct of novelty value was a modified version based on the scales of Bello and Etzel [39] and Weber [7]. The satisfaction scale was adapted from Homburg et al. [40], Patterson and Spreng [41], Petrick and Backman [42], and Spreng et al. [43]. The scales for the constructs of intention to return, search for alternatives, and word-of-mouth referral were adapted from Cronin et al. [37], Eggert and Ulaga [44], Kashyap and Bojanic [45], and Patterson and Spreng [41]. Seven-point Likert-type scales were used to measure all constructs.

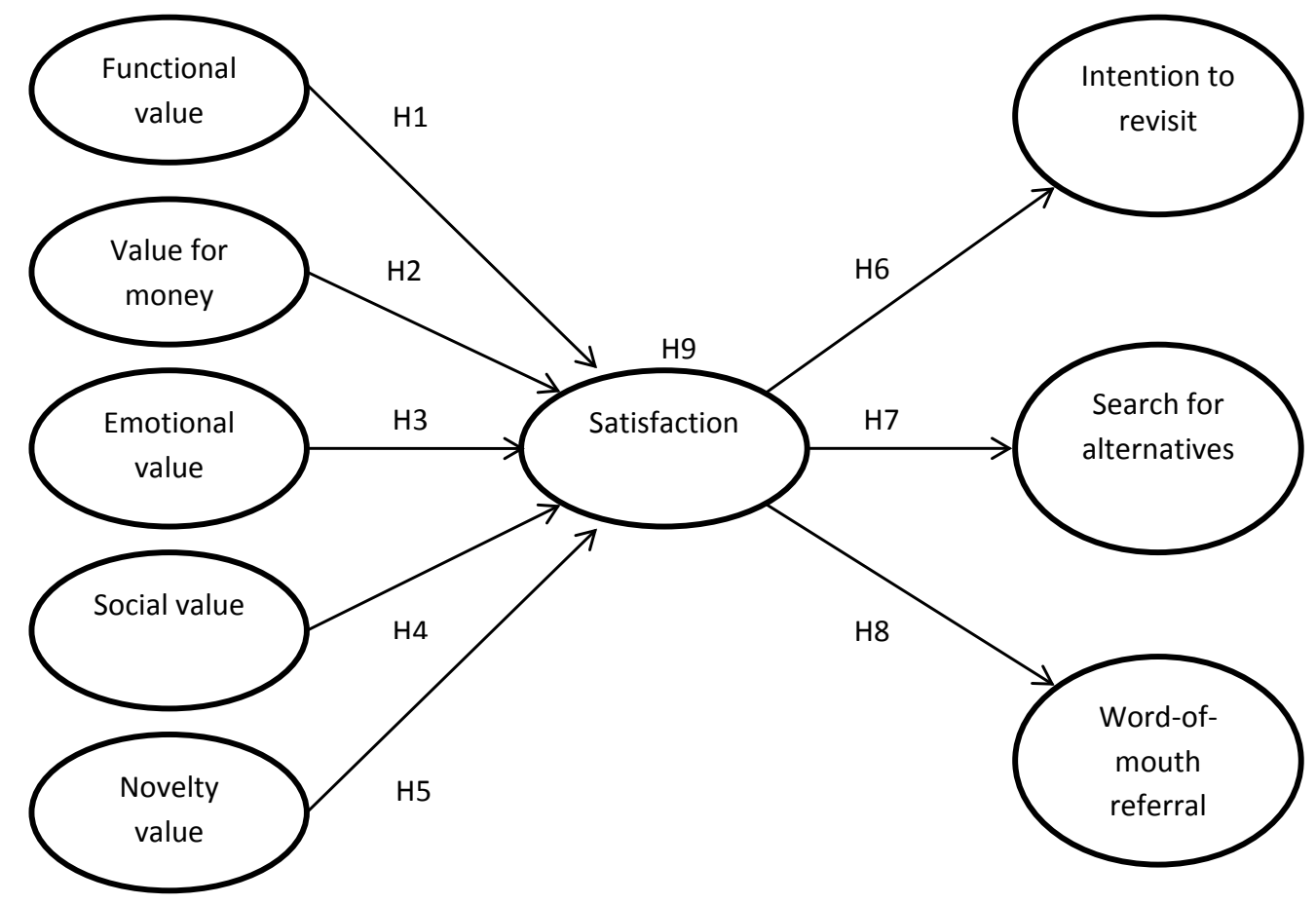

Figure 1. Conceptual model 


\section{Results and discussion}

The demographic analysis was conducted with the use of IBM SPSS Statistics 20.0, while the remaining analyses in this study were completed with SmartPLS 2.0 M3 [46].

\section{Respondent profile}

Table 1 shows the respondents' profile, including their demographics. It contains information concerning the respondents' gender, marital status, age, income, country of origin, education, as well as the type and duration of the adventure training programme attended.

The profile of the respondents highlights diversity, which is one of the main characteristics of the population studied through sampling.

\section{Model results}

The proposed conceptual model was tested with Partial Least Squares Structural Equation Modelling (PLS-SEM). PLSSEM is a component-based approach, and it is generally recommended for prediction and theory building. It even allows model testing without normal distribution of data and can handle relatively small sample size as well. Hence, PLS-SEM was regarded as an appropriate choice to test the conceptual model, as the objectives were prediction and theory building. Figure 2 shows the results of the PLS model with the model indicators.

The indicators of the constructs are assigned symbols in Figure 2. Corresponding items for the symbols are given in Table 2.

\section{Evaluation of measurement model}

The conceptual model was tested with the PLS-SEM technique using SmartPLS software. The measurement model had indicator loadings $\geq 0.70$, which confirms the reliability of the indicators in this model according to Hair, Ringle, and Sarstedt [47]. Table 2 presents the constructs and corresponding items, the loadings for all items, as well as the composite reliability, average variance extracted, and Cronbach's alpha of all constructs.

\section{Reliability analysis}

Composite reliability scores were used to estimate the internal consistency reliability of different constructs. The analysis of the model results resulted in composite reliability scores $\geq 0.85$, which are acceptable; the scores are given in Table 2. Composite reliability scores greater than 0.70 are considered acceptable, and scores between 0.60 and 0.70 are also considered acceptable for exploratory research [47].

Indicator loading values were used to evaluate the reliability of the indicators. According to Hair Jr., Hult, Ringle, and Sarstedt [48], indicator loading values should be higher than 0.70 to ascertain reliability. In this model, all indicators have values $\geq 0.70$; hence, these are inferred to be reliable. Indicator loading values are presented in Table 2 .

Convergent validity was evaluated through average variance extracted (AVE), which should be higher than 0.50 to ascertain convergent validity [48]. All AVE scores in this model have values higher than 0.58 , so convergent validity was demonstrated. AVE scores are shown in Table 2.

Discriminant validity was evaluated using the FornellLarcker criterion. The Fornell-Larcker criterion has the con-

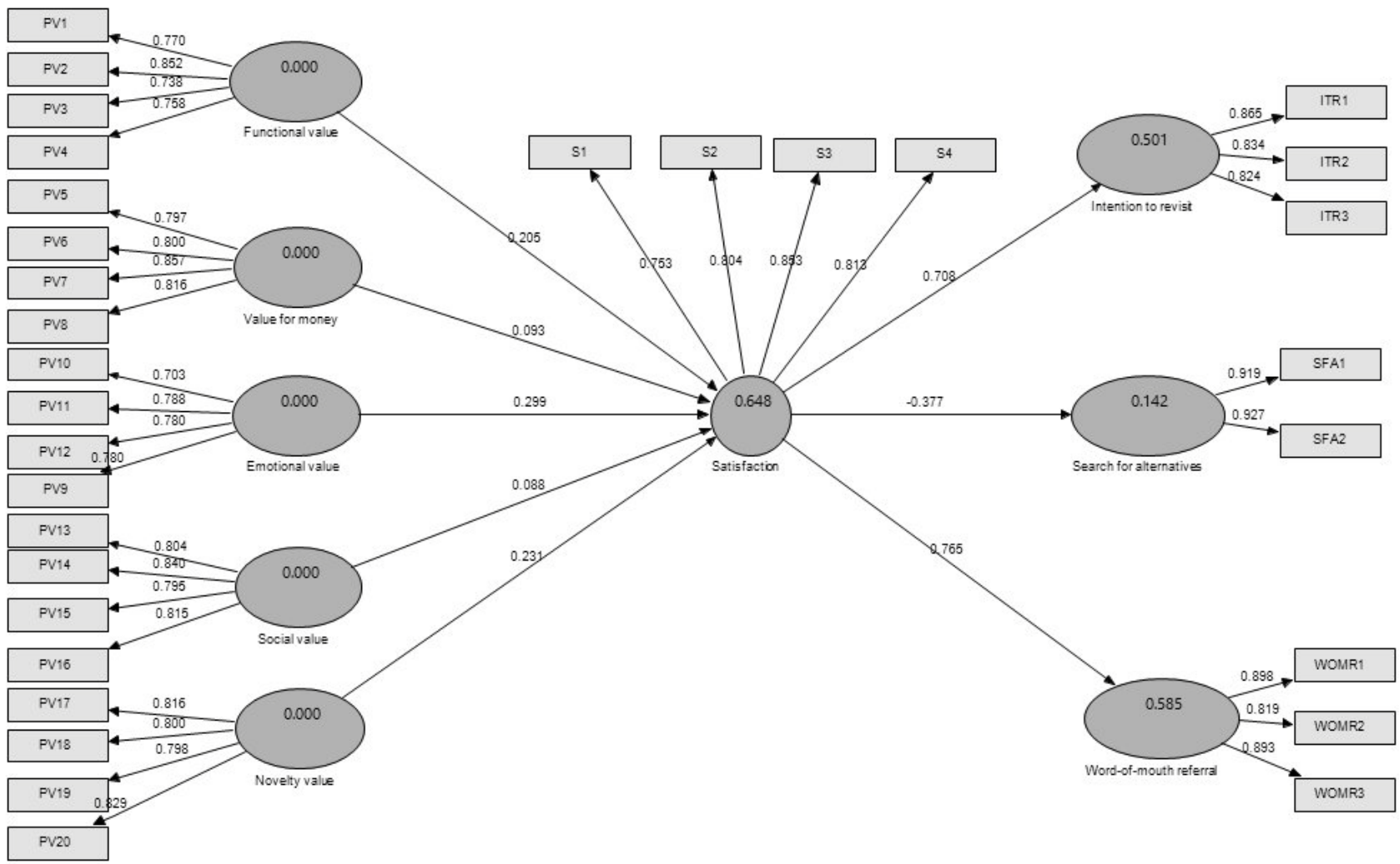

Figure 2. Results of model testing 
Table 1. Respondent profile

\begin{tabular}{|c|c|c|c|}
\hline & & Frequency & Percentage \\
\hline \multirow{2}{*}{ Gender } & Male & 136 & 59.13 \\
\hline & Female & 94 & 40.87 \\
\hline \multirow{2}{*}{ Marital status } & Married & 59 & 25.70 \\
\hline & Single & 171 & 74.30 \\
\hline \multirow{5}{*}{ Age } & 19 years or less & 121 & 52.61 \\
\hline & $20-29$ years & 95 & 41.30 \\
\hline & $30-39$ years & 10 & 4.35 \\
\hline & $40-49$ years & 4 & 1.74 \\
\hline & 50 years or more & 0 & 0 \\
\hline \multirow{5}{*}{$\begin{array}{l}\text { Income } \\
\text { (Indian residents) }\end{array}$} & Less than INR 20,000 & 99 & 45.00 \\
\hline & \begin{tabular}{|l|} 
INR 20,000-39,999 \\
\end{tabular} & 97 & 44.09 \\
\hline & INR 40,000-59,999 & 21 & 09.55 \\
\hline & INR 60,000-79,999 & 3 & 01.36 \\
\hline & INR 80,000-99,999 & 0 & 0 \\
\hline \multirow{6}{*}{$\begin{array}{l}\text { Income } \\
\text { (Foreign residents) }\end{array}$} & Less than USD 2,000 & 0 & 0 \\
\hline & USD 2,000-4,000 & 5 & 50.0 \\
\hline & USD 4,001-6,000 & 3 & 30.0 \\
\hline & USD 6,001-8,000 & 2 & 20.0 \\
\hline & USD 8,000-10,000 & 0 & 0 \\
\hline & Above USD 10,000 & 0 & 0 \\
\hline \multirow{5}{*}{ Country of origin } & India & 220 & 95.65 \\
\hline & \begin{tabular}{|l|} 
United Kingdom \\
\end{tabular} & 2 & 00.87 \\
\hline & France & 3 & 01.30 \\
\hline & USA & 3 & 01.30 \\
\hline & Canada & 2 & 00.87 \\
\hline \multirow{6}{*}{ Education } & Lower than high school & 4 & 01.74 \\
\hline & High school & 67 & 29.13 \\
\hline & $10+2$ & 69 & 30.00 \\
\hline & Graduate & 61 & 26.52 \\
\hline & Post-graduate & 27 & 11.74 \\
\hline & \begin{tabular}{|l|} 
Doctorate \\
\end{tabular} & 2 & 00.87 \\
\hline \multirow{7}{*}{$\begin{array}{l}\text { Adventure training } \\
\text { programme }\end{array}$} & Trekking & 40 & 17.39 \\
\hline & Rock climbing & 15 & 06.52 \\
\hline & Mountaineering & 40 & 17.39 \\
\hline & Adventure & 38 & 16.52 \\
\hline & Water sports & 42 & 18.26 \\
\hline & Skiing & 41 & 17.83 \\
\hline & Mountain biking & 14 & 06.09 \\
\hline \multirow{5}{*}{$\begin{array}{l}\text { Duration of } \\
\text { adventure training }\end{array}$} & 1 day & 0 & 0 \\
\hline & 2 to 7 days & 74 & 32.17 \\
\hline & 8 to 14 days & 116 & 50.43 \\
\hline & 22 to 28 days & 40 & 17.39 \\
\hline & Above 28 days & 0 & 0 \\
\hline
\end{tabular}

Table 2. Psychometric properties of the measurement model

\begin{tabular}{|c|c|c|c|c|c|}
\hline 흘 & $\stackrel{\Xi}{\Phi}$ & 음 & 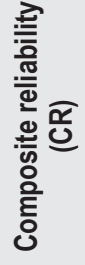 & 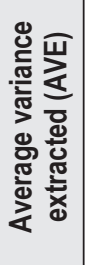 & 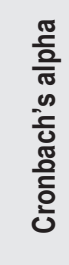 \\
\hline \multirow{4}{*}{$\begin{array}{l}\text { Func- } \\
\text { tional } \\
\text { value }\end{array}$} & Has consistent quality (PV1) & 0.77 & \multirow{4}{*}{0.86} & \multirow{4}{*}{0.61} & \multirow{4}{*}{0.79} \\
\hline & Is well made (PV2) & 0.85 & & & \\
\hline & $\begin{array}{l}\text { Has an acceptable standard } \\
\text { of quality (PV3) }\end{array}$ & 0.74 & & & \\
\hline & Is well organised (PV4) & 0.76 & & & \\
\hline \multirow{4}{*}{$\begin{array}{l}\text { Value } \\
\text { for } \\
\text { money }\end{array}$} & Good return for money (PV5) & 0.80 & \multirow{4}{*}{0.89} & \multirow{4}{*}{0.67} & \multirow{4}{*}{0.83} \\
\hline & Value for money (PV6) & 0.80 & & & \\
\hline & Good for the price paid (PV7) & 0.86 & & & \\
\hline & Reasonably priced (PV8) & 0.82 & & & \\
\hline \multirow{4}{*}{$\begin{array}{l}\text { Emo- } \\
\text { tional } \\
\text { value }\end{array}$} & $\begin{array}{l}\text { Gave me feelings of well- } \\
\text { being (PV9) }\end{array}$ & 0.78 & \multirow{4}{*}{0.85} & \multirow{4}{*}{0.58} & \multirow{4}{*}{0.76} \\
\hline & Was exciting (PV10) & 0.70 & & & \\
\hline & Made me elated (PV11) & 0.79 & & & \\
\hline & Made me feel happy (PV12) & 0.78 & & & \\
\hline \multirow{4}{*}{$\begin{array}{l}\text { Social } \\
\text { value }\end{array}$} & $\begin{array}{l}\text { Gives social approval from } \\
\text { others (PV13) }\end{array}$ & 0.80 & \multirow{4}{*}{0.89} & \multirow{4}{*}{0.66} & \multirow{4}{*}{0.83} \\
\hline & $\begin{array}{l}\text { Makes me feel acceptable to } \\
\text { others (PV14) }\end{array}$ & 0.84 & & & \\
\hline & $\begin{array}{l}\text { Improves the way a person is } \\
\text { perceived (PV15) }\end{array}$ & 0.80 & & & \\
\hline & $\begin{array}{l}\text { Makes a good impression on } \\
\text { other people (PV16) }\end{array}$ & 0.82 & & & \\
\hline \multirow{4}{*}{$\begin{array}{l}\text { Novelty } \\
\text { value }\end{array}$} & $\begin{array}{l}\text { Made me feel adventurous } \\
\text { (PV17) }\end{array}$ & 0.82 & \multirow{4}{*}{0.89} & \multirow{4}{*}{0.66} & \multirow{4}{*}{0.83} \\
\hline & Satisfied my curiosity (PV18) & 0.80 & & & \\
\hline & $\begin{array}{l}\text { Was an authentic experience } \\
\text { (PV19) }\end{array}$ & 0.80 & & & \\
\hline & We did a lot of things (PV20) & 0.83 & & & \\
\hline \multirow{4}{*}{$\begin{array}{l}\text { Satisfac- } \\
\text { tion }\end{array}$} & Pleased with the visit (S1) & 0.75 & \multirow{4}{*}{0.88} & \multirow{4}{*}{0.65} & \multirow{4}{*}{0.82} \\
\hline & Content with the visit (S2) & 0.80 & & & \\
\hline & Delighted with the visit (S3) & 0.85 & & & \\
\hline & Satisfied with the visit (S4) & 0.81 & & & \\
\hline \multirow{3}{*}{$\begin{array}{l}\text { Intention } \\
\text { to } \\
\text { return }\end{array}$} & Intention to return (ITR1) & 0.87 & \multirow{3}{*}{0.88} & \multirow{3}{*}{0.71} & \multirow{3}{*}{0.79} \\
\hline & Most likely to return (ITR2) & 0.83 & & & \\
\hline & $\begin{array}{l}\text { High likelihood of return } \\
\text { (ITR3) }\end{array}$ & 0.82 & & & \\
\hline \multirow{2}{*}{$\begin{array}{l}\text { Search } \\
\text { for alter- } \\
\text { natives }\end{array}$} & $\begin{array}{l}\text { Put effort into looking for } \\
\text { alternative (SFA1) }\end{array}$ & 0.92 & \multirow{2}{*}{0.92} & 085 & 083 \\
\hline & $\begin{array}{l}\text { Continuous search for alter- } \\
\text { native (SFA2) }\end{array}$ & 0.93 & & 0.00 & 0.00 \\
\hline & $\begin{array}{l}\text { Would positively recommend } \\
\text { to other people (WOMR1) }\end{array}$ & 0.90 & & & \\
\hline $\begin{array}{l}\text { Word-of- } \\
\text { mouth }\end{array}$ & $\begin{array}{l}\text { Would be glad to recommend } \\
\text { to other people (WOMR2) }\end{array}$ & 0.82 & 0.90 & 0.76 & 0.84 \\
\hline ref & $\begin{array}{l}\text { Would recommend to those } \\
\text { who are planning participa- } \\
\text { tion (WOMR3) }\end{array}$ & 0.89 & & & \\
\hline
\end{tabular}


Table 3. Inter-construct correlations

\begin{tabular}{|c|c|c|c|c|c|c|c|c|c|}
\hline & 1 & 2 & 3 & 4 & 5 & 6 & 7 & 8 & 9 \\
\hline 1. Functional value & 0.781 & & & & & & & & \\
\hline 2. Value for money & 0.603 & 0.818 & & & & & & & \\
\hline 3. Emotional value & 0.727 & 0.737 & 0.764 & & & & & & \\
\hline 4. Social value & 0.666 & 0.650 & 0.752 & 0.814 & & & & & \\
\hline 5. Novelty value & 0.637 & 0.670 & 0.744 & 0.700 & 0.811 & & & & \\
\hline 6. Satisfaction & 0.684 & 0.649 & 0.754 & 0.671 & 0.708 & 0.807 & & & \\
\hline 7. Intention to revisit & 0.553 & 0.571 & 0.688 & 0.621 & 0.622 & 0.708 & 0.841 & & \\
\hline 8. Search for alternatives & -0.345 & -0.311 & -0.382 & -0.347 & -0.354 & -0.377 & -0.393 & 0.923 & \\
\hline 9. Word-of-mouth referral & 0.625 & 0.578 & 0.717 & 0.641 & 0.665 & 0.765 & 0.694 & -0.491 & 0.871 \\
\hline
\end{tabular}

Note: Square root of average variance extracted (AVE) is shown on the diagonal of the matrix. Inter-construct correlation is shown off the diagonal.

dition that the square root of AVE should be higher than the inter-construct correlation to conclude discriminant validity [47]. This measurement model satisfies this condition, and discriminant validity was confirmed for all constructs. The values of the inter-construct correlations and the square root of AVE are given in Table 3 for evaluation of discriminant validity.

\section{Evaluation of structural model}

The structural model was examined to test the hypotheses proposed in this study. The evaluation of the structural model was conducted using path loadings and $\mathrm{R}^{2}$ values. Path loading values were used to assess the strength of the relationships between exogenous and endogenous variables. The predictive power of the model was evaluated using $\mathrm{R}^{2}$ values. Table 4 presents the $R^{2}$ values of endogenous constructs.

The values of $\mathrm{R}^{2}$ for this model indicate relatively good predictive power. This model explains $64.8 \%$ of variance in satisfaction, $50.1 \%$ of variance in the intention to revisit, $14.2 \%$ of variance in the search for alternatives, and $58.5 \%$ of variance in word-of-mouth referral.
The significance of path coefficients was assessed with the help of t-values which were obtained through the application of the bootstrapping technique. Bootstrapping was performed on a model with 5,000 samples and 230 cases.

The relationship between novelty value and satisfaction was found to be significant at the level of $5 \%$. However, the relationships between functional value and satisfaction, emotional value and satisfaction, satisfaction and the intention to revisit, as well as the search for alternatives and word-of-mouth referral were found to be significant at the level of $1 \%$. Relationships between social value as well as value for money and satisfaction were insignificant.

Therefore, hypotheses $\mathrm{H}_{2}$ and $\mathrm{H}_{4}$ were not supported, and insignificant relationships were found for these hypotheses. However, hypotheses $\mathrm{H}_{1}, \mathrm{H}_{3}, \mathrm{H}_{5}, \mathrm{H}_{6}, \mathrm{H}_{7}$, and $\mathrm{H}_{8}$ were supported, and, in these cases, significant relationships were found. The bootstrapping results are presented in Table 5 .

Critical t-values for a two-tailed test are 1.65 for the significance level of $10 \%, 1.96$ for that of 5\%, and 2.58 at the level of $1 \%$.

Table 4. $\mathrm{R}^{2}$ values

\begin{tabular}{|c|c|c|c|c|}
\hline & Satisfaction & Intention to revisit & Search for alternatives & Word-of-mouth referral \\
\hline$R^{2}$ & 0.648 & 0.501 & 0.142 & 0.585 \\
\hline
\end{tabular}

Table 5. Path coefficients (Mean, STDEV, T-values)

\begin{tabular}{|c|c|c|c|c|c|}
\hline & $\begin{array}{l}\text { Original sample } \\
\text { (0) }\end{array}$ & $\begin{array}{l}\text { Sample mean } \\
\text { (M) }\end{array}$ & $\begin{array}{c}\text { Standard deviation } \\
\text { (STDEV) }\end{array}$ & $\begin{array}{l}\text { Standard error } \\
\text { (STERR) }\end{array}$ & $\begin{array}{l}\text { T Statistics } \\
\text { (|O/STERR|) }\end{array}$ \\
\hline Functional value $\rightarrow$ Satisfaction & 0.205 & 0.205 & 0.062 & 0.062 & $3.296^{* \star *}$ \\
\hline Value for money $\rightarrow$ Satisfaction & 0.093 & 0.099 & 0.073 & 0.073 & 1.277 \\
\hline Emotional value $\rightarrow$ Satisfaction & 0.299 & 0.291 & 0.081 & 0.081 & $3.687^{\star \star *}$ \\
\hline Social value $\rightarrow$ Satisfaction & 0.088 & 0.087 & 0.087 & 0.087 & 1.014 \\
\hline Novelty value $\rightarrow$ Satisfaction & 0.231 & 0.232 & 0.094 & 0.094 & $2.427^{* *}$ \\
\hline Satisfaction $\rightarrow$ Intention to revisit & 0.708 & 0.702 & 0.060 & 0.060 & $11.704^{* * *}$ \\
\hline Satisfaction $\rightarrow$ Search for alternatives & -0.377 & -0.375 & 0.102 & 0.101 & $3.707^{* * *}$ \\
\hline Satisfaction $\rightarrow$ Word-of-mouth referral & 0.765 & 0.759 & 0.057 & 0.057 & $13.495^{* * *}$ \\
\hline
\end{tabular}

${ }^{* * *}=$ significant at 0.01 level; ${ }^{* *}=$ significant at 0.05 level; ${ }^{*}=$ significant at 0.1 level; values without asterisks are not significant. 


\section{Customer satisfaction as a mediator between service} value and behavioural intentions

Mediation effects were tested according to the procedure suggested by Preacher and Hayes [49]. The values of direct effect, indirect effect, and variance accounted for (VAF) are exhibited in Table 6 . In the first step, direct effects were assessed without including a mediator variable in the PLS path model, and these were found to be significant. In the second step, the mediator variable was included in the PLS path model, and the significance of indirect effects were assessed. Indirect effects were also found to be significant. After assessing the significance of the indirect effect, variance accounted for (VAF) was calculated to find the degree of mediation. Since all VAF values were between $20 \%$ and $80 \%$, partial mediation of customer satisfaction was established between various dimensions of service value and behavioural intentions. Therefore, hypothesis $\mathrm{H}_{9}$ was supported. According to Hair Jr. et al., VAF $>80 \%$ is a case of full mediation, while $20 \% \leq \mathrm{VAF} \leq 80 \%$ is partial mediation, and $\mathrm{VAF} \leq 20 \%$ is a scenario of no mediation [48].

This suggests that the greater the degree of service value is, the greater customer satisfaction is, and this induces positive behavioural intentions.

\section{Conclusions}

This study has confirmed the significant positive influence of functional value, emotional value, and novelty value on adventure trainees' satisfaction. However, the influence of social value and value for money on adventure trainees' satisfaction was insignificant. Relationships between the satisfaction of adventure trainees and their behavioural intentions (intention to revisit, search for alternatives, and word-of-mouth referral) were significant as hypothesised. Satisfaction had a direct positive influence on the intention to revisit and word-of-mouth referral, whereas it had a negative influence on the search for alternatives. The results for the relationships between satisfac- tion and future behavioural intentions are consistent with those obtained in another study on adventure tourists by Chandel and Bansal [20]. Satisfaction was demonstrated to have a partial mediation effect on the relationships between the five dimensions of service value and behavioural intentions. This study confirms previous studies in which satisfaction has mediated between service value and intention relationships $[23,37,38]$.

This model has been shown to have good predictive power for endogenous constructs, as it explained $64.8 \%$ of the variance in the adventure trainees' satisfaction, $58.5 \%$ in word-of-mouth referral, $14.2 \%$ in the search for alternatives, and $50.1 \%$ in the intention to revisit.

\section{Managerial implications}

The results of this study have several useful implications for the management of adventure education and training centres. First, functional value has been demonstrated to have a significant influence on adventure trainees' satisfaction. Therefore, adventure education and training centres should focus on the design, quality, and organisation of training programmes so as to enhance the satisfaction of adventure trainees.

Second, emotional value has been shown to have a significant influence on adventure trainees' satisfaction. Therefore, the management of adventure education and training centres should focus on improving emotional value from adventure training programmes. Emotional value associated with adventure training programmes could be improved through the delivery of experiences which produce the feelings of well-being, excitement, elation, and happiness during each stage of the programme. These elements will enhance the satisfaction of adventure trainees.

Third, novelty value has been demonstrated to significantly influence the satisfaction of adventure trainees. The management of adventure education and training centres need to design and deliver training programmes in such a way that adventure trainees experience novelty during different stages. The

Table 6. Customer satisfaction as a mediator between service value and behavioural intentions

\begin{tabular}{|c|c|c|c|c|c|}
\hline & Direct & & Indirec & & Variance accounted \\
\hline & Path coefficient & $\mathrm{t}$ & Path coefficient & $\mathrm{t}$ & for (VAF) \\
\hline Functional value $\rightarrow$ Intention to revisit & 0.557 & $7.55^{\star \star *}$ & 0.421 & $6.01^{* * *}$ & 0.430 \\
\hline Value for money $\rightarrow$ Intention to revisit & 0.575 & $8.01^{* * *}$ & 0.378 & $5.74^{* * *}$ & 0.396 \\
\hline Emotional value $\rightarrow$ Intention to revisit & 0.693 & $10.82^{* \star *}$ & 0.328 & $5.43^{* * *}$ & 0.321 \\
\hline Social value $\rightarrow$ Intention to revisit & 0.626 & $8.70^{* * *}$ & 0.353 & $5.70^{* * *}$ & 0.361 \\
\hline Novelty value $\rightarrow$ Intention to revisit & 0.625 & $8.27^{* * *}$ & 0.378 & $6.32^{* * *}$ & 0.377 \\
\hline Functional value $\rightarrow$ Search for alternatives & -0.349 & $3.69^{\star \star *}$ & -0.180 & $-2.41^{* *}$ & 0.340 \\
\hline Value for money $\rightarrow$ Search for alternatives & -0.312 & $3.33^{* * *}$ & -0.196 & $-2.87^{\star * *}$ & 0.386 \\
\hline Emotional value $\rightarrow$ Search for alternatives & -0.39 & $3.73^{* * *}$ & -0.154 & $-2.20^{* *}$ & 0.283 \\
\hline Social value $\rightarrow$ Search for alternatives & -0.358 & $3.81^{* * *}$ & -0.174 & $-2.38^{* *}$ & 0.328 \\
\hline Novelty value $\rightarrow$ Search for alternatives & -0.36 & $3.44^{* * *}$ & -0.177 & $-2.48^{* *}$ & 0.329 \\
\hline Functional value $\rightarrow$ Word-of-mouth referral & 0.635 & $10.51^{\star * *}$ & 0.432 & $5.94^{* * *}$ & 0.405 \\
\hline Value for money $\rightarrow$ Word-of-mouth referral & 0.58 & $7.54^{\star \star \star}$ & 0.437 & $6.64^{* * *}$ & 0.430 \\
\hline Emotional value $\rightarrow$ Word-of-mouth referral & 0.719 & $11.15^{\star * *}$ & 0.390 & $5.84^{* * *}$ & 0.352 \\
\hline Social value $\rightarrow$ Word-of-mouth referral & 0.641 & $9.17^{\star * \star}$ & 0.410 & $5.64^{* * *}$ & 0.390 \\
\hline Novelty value $\rightarrow$ Word-of-mouth referral & 0.667 & 7.81 & 0.416 & $5.99^{* * *}$ & 0.384 \\
\hline
\end{tabular}

${ }^{* * *}=$ significant at 0.01 level, ${ }^{* *}=$ significant at 0.05 level, ${ }^{*}=$ significant at 0.1 level; values without asterisks are not significant. 
design of training programmes should include diverse authentic adventure activities to satisfy participants' curiosity. Innovations in the design and delivery of training programmes have the potential to deliver novelty value to participants. Improvements in this area will positively influence adventure trainees' satisfaction.

Fourth, adventure trainees' satisfaction was found to have a significant influence on their future behavioural intentions. Adventure trainees' satisfaction had a significant direct positive influence on the intention to revisit and word-of-mouth referrals, while having a significant negative influence on the search for alternatives. The management of adventure education and training centres need to enhance trainees' satisfaction to elicit positive future behaviour in terms of revisits and word-ofmouth referrals by their users.

Fifth, adventure trainees' satisfaction has been found to partially mediate between the multidimensional construct of service value and behavioural intentions. This indicates that attempts should be made to improve service value to elicit higher satisfaction and, as a result, favourable behavioural intentions.

This study has confirmed that the functional, emotional, and novelty values act as significant antecedents to adventure trainees' satisfaction, which subsequently triggers positive future behaviour among adventure trainees.

\section{Limitations and future research directions}

This study has contributed to filling the knowledge gap in the literature of adventure education and training, but it has limitations as well. First, if the external validity of results is to be increased, there is need to include more diverse adventure education and training programmes in different geographical regions. Future studies may be conducted on more diverse adventure education and training programmes in different geographical areas with different environmental settings. Second, this study has only focused on adventure training programmes whose duration was more than 24 hours. Adventure education and training programmes of less than 24 hours' duration may give different results. Thus, adventure education and training programmes of less than 24 hours may be examined by researchers in the future as well. Third, adventure education and training programmes may also be classified according to different parameters, such as the level (basic, intermediate, advanced, and instructor), the degree of risk, and the challenge they pose. Studies on these different segments may give different insights about adventure education and training. Fourth, heterogeneity in the participants of adventure education and training could be examined with the application of finite-mixture partial least squares (FIMIX-PLS) technique to the model.

\section{Literature}

1. Priest S. (1996). The relationship among change, program type and facilitation technique in adventure programming. The Journal of Adventure Education and Outdoor Leadership 13(2), 22-26.

2. Sweeney J.C., Soutar G.N., Johnson L.W. (1999). The role of perceived risk in the quality-value relationship: A study in a retail environment. Journal of Retailing 75(1), 77-105.

3. Zeithaml V.A. (1988). Consumer perceptions of price, quality, and value: A means-end model and synthesis of evidence. Journal of Marketing 52(3), 2-22.

4. Sweeney J.C., Soutar G.N. (2001). Consumer perceived value: The development of a multiple item scale. Journal of Retailing 77(2), 203-220. DOI: 10.1016/S0022-4359(01)00041-0.
5. Sheth J.N., Newman B.I., Gross B.L. (1991). Consumption values and market choices: Theory and applications. Cincinnati, OH: South-Western Pub.

6. Hall C.M., Weiler B. (1992). Introduction: What's so special about special interest tourism? In B. Weiler, C.M. Hall (eds.), Special interest tourism. London: Belhaven Press.

7. Weber K. (2001). Outdoor adventure tourism: A review of research approaches. Annals of Tourism Research 28(2), 360-377.

8. Fornell C. (1992). A national customer satisfaction barometer: The Swedish experience. Journal of Marketing 56(1), 6-21.

9. Fonseca J.R.S. (2009). Customer satisfaction study via a latent segment model. Journal of Retailing and Consumer Services 16(5), 352-359.

10. Baker D.A., Crompton J.L. (2000). Quality, satisfaction and behavioral intentions. Annals of Tourism Research 27(3), 785-804.

11. Zeithaml V.A., Berry L.L., Parasuraman A. (1996). The behavioral consequences of service quality. Journal of Marketing 60(2), 31.

12. Calabuig Moreno F., Prado-Gascó V., Crespo Hervás J., Núñez-Pomar J., Añó Sanz V. (2015). Spectator emotions: Effects on quality, satisfaction, value, and future intentions. Journal of Business Research 68(7), 1445-1449. DOI: 10.1016/j.jbusres.2015.01.031.

13. Chen C.-F., Tsai M.-H. (2008). Perceived value, satisfaction, and loyalty of TV travel product shopping: Involvement as a moderator. Tourism Management 29(6), 1166-1171. DOI: 10.1016/j.tourman.2008.02.019.

14. Gallarza M.G., Gil Saura I. (2006). Value dimensions, perceived value, satisfaction and loyalty: An investigation of university students' travel behaviour. Tourism Management 27(3), 437-452. DOI: 10.1016/j.tourman.2004.12.002.

15. Howat G., Assaker G. (2013). The hierarchical effects of perceived quality on perceived value, satisfaction, and loyalty: Empirical results from public, outdoor aquatic centres in Australia. Sport Management Review 16(3), 268-284. DOI: 10.1016/j.smr.2012.10.001.

16. Hutchinson J., Lai F., Wang Y. (2009). Understanding the relationships of quality, value, equity, satisfaction, and behavioral intentions among golf travelers. Tourism Management 30(2), 298-308. DOI: 10.1016/j.tourman.2008.07.010.

17. Lai W.-T., Chen C.-F. (2011). Behavioral intentions of public transit passengers - The roles of service quality, perceived value, satisfaction and involvement. Transport Policy 18(2), 318-325. DOI: 10.1016/j.tranpol.2010.09.003.

18. Bojanic D.C. (1996). Consumer perceptions of price, value and satisfaction in the hotel industry: An exploratory study. Journal of Hospitality and Leisure Management 4(1), 5-22.

19. Williams P., Soutar G. (2005). Close to the "edge": Critical issues for adventure tourism operators. Asia $\mathrm{Pa}$ cific Journal of Tourism Research 10(3), 247-261. DOI: $10.1080 / 10941660500309614$.

20. Chandel J.K., Bansal S.P. (2014). Understanding the relationships of value, satisfaction and behavioural intentions among adventure tourists. International Journal of Leisure and Tourism Marketing 4(2), 156-171.

21. Choi E.J., Kim S. (2013). The study of the impact of perceived quality and value of social enterprises on customer satisfaction and re-purchase intention. International Journal of Smart Home 7(1), 239-252.

22. Khan N., Kadir S.L.S.A., Wahab S.A. (2010). Investigating structure relationship from functional and relational value 
to behavior intention: The role of satisfaction and relationship commitment. International Journal of Business and Management 5(10), 20-36.

23. Williams P., Soutar G.N. (2009). Value, satisfaction and behavioral intentions in an adventure tourism context. Annals of Tourism Research 36(3), 413-438. DOI: 10.1016/j.annals.2009.02.002.

24. McDougall G.H.G., Levesque T. (2000). Customer satisfaction with services: Putting perceived value into the equation. Journal of Services Marketing 14(5), 392-410. DOI: 10.1108/08876040010340937.

25. Otto J.E., Ritchie J.R.B. (1996). The service experience in tourism. Tourism Management 17(3), 165-174.

26. Feng R., Jang S. (2004). Temporal destination loyalty: A structural initiation. Advances in Hospitality and Tourism Research 9, 207-221.

27. Alvarado A., Beltrán S. (2008). The effects of spectators' emotional and evaluative satisfaction concerning their intentions to attend events and recommending them to others. Innovar 18(32), 75-86. [in Spanish]

28. Caruana A. (2002). Service loyalty: The effects of service quality and the mediating role of customer satisfaction. European Journal of Marketing 36(7), 811-828.

29. Cronin J.J., Taylor S.A. (1992). Measuring service quality: A reexamination and extension. Journal of Marketing 56(3), 55-68. DOI: 10.2307/1252296.

30. Flint D.J., Blocker C.P., Boutin P.J. (2011). Customer value anticipation, customer satisfaction and loyalty: An empirical examination. Industrial Marketing Management 40(2), 219-230. DOI: 10.1016/j.indmarman.2010.06.034.

31. Lee S., Jeon S., Kim D. (2011). The impact of tour quality and tourist satisfaction on tourist loyalty: The case of Chinese tourists in Korea. Tourism Management 32(5), 1115-1124. DOI: 10.1016/j.tourman.2010.09.016.

32. Olsen S.O. (2002). Comparative evaluation and the relationship between quality, satisfaction, and repurchase loyalty. Journal of the Academy of Marketing Science 30(3), 240-249.

33. Ryu K., Han H., Kim T.-H. (2008). The relationships among overall quick-casual restaurant image, perceived value, customer satisfaction, and behavioral intentions. International Journal of Hospitality Management 27(3), 459-469. DOI: 10.1016/j.ijhm.2007.11.001.

34. Beeho A.J., Prentice R.C. (1997). Conceptualizing the experiences of heritage tourists: A case study of New Lanark World Heritage Village. Tourism Management 18(2), 75-87. DOI: 10.1016/S0261-5177(96)00103-3.

35. Som A.P.M., Badarneh M.B. (2011). Tourist satisfaction and repeat visitation: Toward a new comprehensive model. World Academy of Science, Engineering and Technology 5, 973-980.

36. Kozak M., Rimmington M. (2000). Tourist satisfaction with Mallorca, Spain, as an off-season holiday destina- tion. Journal of Travel Research 38(3), 260-269. DOI: 10.1177/004728750003800308.

37. Cronin J.J., Brady M.K., Hult G.T.M. (2000). Assessing the effects of quality, value, and customer satisfaction on consumer behavioral intentions in service environments. Journal of Retailing 76(2), 193-218. DOI: 10.1016/S00224359(00)00028-2.

38. Lam S.Y., Shankar V., Erramilli M.K., Murthy B. (2004). Customer value, satisfaction, loyalty, and switching costs: An illustration from business-to-business service context. Academy of Marketing Science 32(3), 293-311.

39. Bello D.C., Etzel M.J. (1985). The role of novelty in the pleasure travel experience. Journal of Travel Research 24(1), 2026.

40. Homburg C., Koschate N., Hoyer W.D. (2005). Do satisfied customers really pay more? A study of the relationship between customer satisfaction and willingness to pay. Journal of Marketing 69(2), 84-96.

41. Patterson P.G., Spreng R.A. (1997). Modelling the relationship between perceived value, satisfaction and repurchase intentions in a business-to-business, services context: An empirical examination. International Journal of Service Industry Management 8(5), 414-434.

42. Petrick J.F., Backman S.J. (2002). An examination of the construct of perceived value for the prediction of golf travelers' intentions to revisit. Journal of Travel Research 41(1), 38-45.

43. Spreng R.A., MacKenzie S.B., Olshavsky R.W. (1996). A reexamination of the determinants of consumer satisfaction. Journal of Marketing 60(3), 15.

44. Eggert A., Ulaga W. (2002). Customer perceived value: A substitute for satisfaction in business markets? Journal of Business Industrial Marketing 17(2/3), 107-118.

45. Kashyap R., Bojanic D.C. (2000). A structural analysis of value, quality, and price perceptions of business and leisure travellers. Journal of Travel Research 39(1), 45-51.

46. Ringle C.M., Wende S., Will A. (2005). SmartPLS. Hamburg, Germany: SmartPLS. Retrieved from http://www. smartpls.de.

47. Hair J.F., Ringle C.M., Sarstedt M. (2011). PLS-SEM: Indeed a silver bullet. The Journal of Marketing Theory and Practice 19(2), 139-152. DOI: 10.2753/MTP1069-6679190202.

48. Hair Jr. J.F., Hult G.T.M., Ringle C.M., Sarstedt M. (2014). A Primer on Partial Least Squares Structural Equation Modeling (PLS-SEM). Thousand Oaks, CA: Sage Publications, Inc.

49. Preacher K.J., Hayes A.F. (2008). Asymptotic and resampling strategies for assessing and comparing indirect effects in multiple mediator models. Behavior Research Methods 40(3), 879-891. DOI: 10.3758/BRM.40.3.879.

Submitted: June 2, 2017

Accepted: October 23, 2017 